\title{
Organochlorine Pesticide Residues and Microbiological Quality Assessment of Dried Barb, Puntius sophore, from the Northeastern Part of Bangladesh
}

\author{
Md. Ashraf Hussain ${ }^{1,2}$, Md. Lutful Kabir ${ }^{1}$, Md. Abu Sayeed ${ }^{1}$, A.T.M. Mahbub-E-Elahi ${ }^{3}$, \\ Md. Sultan Ahmed ${ }^{4}$ and Md Jakiul Islam ${ }^{1, * \mathbb{D}}$ \\ 1 Department of Fisheries Technology and Quality Control, Faculty of Fisheries, Sylhet Agricultural \\ University, Sylhet-3100, Bangladesh; ashraf.sau.bd@gmail.com (M.A.H.); shihab.sau27@gmail.com (M.L.K.); \\ sayeedsau@gmail.com (M.A.S.) \\ 2 Department of Fisheries, Ministry of Fisheries and Livestock, Dhaka-1000, Bangladesh \\ 3 Department of Microbiology and Immunology, Faculty of Veterinary, Animal and Biomedical Science, \\ Sylhet Agricultural University, Sylhet-3100, Bangladesh; atm.mahbub.elahi@gmail.com \\ 4 Bangladesh Agricultural Research Institute, Gazipur-1701, Bangladesh; sultan.palbari@gmail.com \\ * Correspondence: jakiulmi@sau.ac.bd; Tel.: +880-1717-337-521
}

Received: 13 September 2018; Accepted: 5 November 2018; Published: 9 November 2018

\begin{abstract}
The present study was carried out in the northeastern part of Bangladesh to investigate organochlorine pesticide (OCP) residues in and microbiological quality of dried barb (Puntius sophore). Samples were collected from both producers and retailers from December 2016 to April 2017. A control sample was also prepared in the laboratory with the same raw fish used by the producers to compare the results. Gas chromatography with electron capture detector (GC-ECD) was used to detect and quantify OCP residues. Six samples out of 27 (about $22 \%$ ) were found to be contaminated with OCP residues. Among these six adulterated samples, four were from retailers and two from producers. Only aldrin was detected in four samples, and in the other two samples both aldrin + dieldrin and aldrin + endrin were detected. Aldrin was found in quantities between 0.332 and $0.967 \mathrm{ppm}$, dieldrin $0.762 \mathrm{ppm}$, and endrin $0.828 \mathrm{ppm}$. All these values were much higher than the maximum residual limit (MRL) of $0.1 \mathrm{ppm}$. Total plate count (TPC) of producer samples ranged from $5.3 \pm 0.02 \mathrm{log}$ cfu g ${ }^{-1}$ to $5.4 \pm 0.03 \log$ cfu g $^{-1}$ and $6.2 \pm 0.02 \log$ cfu g $^{-1}$ to $6.4 \pm 0.02 \log$ cfu g $^{-1}$ for retailer samples and $5.0 \pm 0.03 \mathrm{log} \mathrm{cfu} \mathrm{g}^{-1}$ to $5.2 \pm 0.04 \mathrm{log}_{\mathrm{cfu}}{ }^{-1}$ for control samples. Fungal count ranged from $3.2 \pm 0.04 \log$ cfu g $^{-1}$ to $3.5 \pm 0.04 \log$ cfu g $^{-1}, 3.4 \pm 0.04 \log _{\text {cfu g }}{ }^{-1}$ to $3.6 \pm 0.03 \log$ cfu $\mathrm{g}^{-1}$, and $2.2 \pm 0.05 \log \mathrm{cfu} \mathrm{g}^{-1}$ to $2.5 \pm 0.03 \mathrm{log}_{\mathrm{cfu}} \mathrm{g}^{-1}$ for producer, retailer, and control samples, respectively. All the producer and retailer samples and one-third of the control samples were found to be contaminated with Escherichia coli, whereas Salmonella spp. were detected in amounts of $13.3 \%$ in producer samples and $20 \%$ in retailer samples and none in the control. In case of Vibrio spp., maximum count was found in retailer samples (13.3\%), whereas producer and control samples showed none. The findings of the present study show that the presence of pesticides and poor microbiological quality of dried barb are alarming for consumers in Bangladesh and might cause prolonged disease and impending longstanding risk to human health.
\end{abstract}

Keywords: dried fish; Puntius sophore; organochlorine pesticide residues; gas chromatography; microbiological quality

\section{Introduction}

Bangladesh is one of the world's leading fish producing countries with a total production of 3.68 million metric tons (MT) in 2014-2015. Almost $60 \%$ of animal protein consumed by the population 
of Bangladesh comes from fish [1]. Every year a significant portion of total harvested fish is sundried due to high market demand. Moreover, a lack of proper storage facilities and unsold fish from the markets force the processing of dried fish. Among other fishery products, dried fish is one of the cheapest and most popular dietary protein sources in Bangladesh [2]. Bangladesh exported 3106 MT of dried fish, representing $3.71 \%$ of total exported fishery products [1].

Unfortunately, there are frequent complaints about the quality of traditionally dried fish, as sanitation and hygiene are rarely practiced. The traditional drying of fish is mainly performed by poor and illiterate producers whose process consists of spreading fish on split bamboo mats, concrete floors, or raised platforms or hanging fish over bamboo poles and bars [3]. One of the major problems associated with dried fish is infestation by varieties of insects such as beetles, mites, and blowflies [2,4,5]. The extent of damage (loss of soft tissue and weight loss) caused by the larvae and adult insects depends largely on the speed of drying, the size of the fish, and whether the fish is salted [6]. In Bangladesh, to protect dried fish from infestation and extend storage time, producers frequently use organochlorine pesticides like dichlorodiphenyltrichloroethane (DDT), dichlorvos, heptachlor, or whatever they can get or is within their reach [7-10].

Death of vegetative bacteria cells is caused by drying of fish, but drying has only a small influence on bacteria and mold spores because of their resistance to extended drying phases and stability when dried [11]. Insufficient protection of dried fish kept under tropical humid conditions [12] might cause insect infestation [13] and microbial proliferation [11]. The weather of Bangladesh is humid, and producers do not dry fish properly because they fear there will be too much weight loss to make enough profit. The quality of salted and dried fish is severely affected by the presence of pathogenic microorganisms [14]. Raw fish used to produce dried fish products frequently get contaminated with microbes from the environment where the fish are caught, and during handling and processing $[4,8]$. Processed and semipreserved or improperly preserved (dried/partially dried) fish have been associated with fishborne disease outbreaks involving Staphylococcus aureus, Escherichia coli, Clostridium botulinum, Streptococcus faecalis, Salmonella spp., Shigella spp., and Bacillus spp. [11,15]. Aflatoxin contamination in dried, salted, and smoked fish and fish products has been reported in the Philippines, Thailand, Indonesia [16], Tanzania [17], and India [18,19]. Therefore, assessing the microbiological quality of salted and sundried fish is vital to safeguard human health and hygiene [20].

A substantial amount of dried fish is produced per annum in Sylhet, in the northeastern part of Bangladesh, because of the availability of raw materials from local water bodies, especially from haors (the local name for bowl-shaped wetland ecosystems). Dried barb (Puntius sophore) is highly produced and one of the most popular dried fish in the Sylhet region. To date, however, there has been no research regarding the microbiological quality and analysis of pesticide residue of this dried fish. The current study was aimed at investigating organochlorine pesticide residue and assessing the microbiological quality of dried barb collected from the northeastern part of Bangladesh.

\section{Results}

\subsection{Pesticide Analysis}

Results of the analysis are presented in Table 1 and Figures 1 and 2. Nine samples from each source were analyzed for detection of organochlorine pesticides (OCPs). OCP residues were detected in six of 27 samples of dried barb. Among these six adulterated samples, two were from producers and four were from retailers. Aldrin was found in all six adulterated samples. The concentration of aldrin in producer samples was $0.617 \mathrm{ppm}$ and $0.812 \mathrm{ppm}$. Aldrin was also detected in two samples from retailers at a concentration of $0.332 \mathrm{ppm}$ and $0.479 \mathrm{ppm}$. Four samples were found contaminated with aldrin, and in the remaining samples both aldrin + dieldrin and aldrin + endrin were detected. The highest concentration of aldrin $(0.967 \mathrm{ppm})$ was found in retailer samples, while the lowest concentration of aldrin $(0.332 \mathrm{ppm})$ was found in producer samples. All the detected organochlorine pesticide residue levels were above the maximum residual limit (MRL) (0.1 ppm) recommended 
by the Australian Pesticides and Veterinary Medicines Authority [21] and the US Food and Drug Administration (FDA) [22]. All the control samples were found free of organochlorine pesticide contamination. To the best of our knowledge, the information on aldrin, dieldrin, and endrin residue in dried fish was scarce for the present study area and for Bangladesh.

Table 1. Concentrations of different organochlorine pesticides detected in dried barb collected from the study areas.

\begin{tabular}{|c|c|c|c|c|c|c|c|}
\hline \multirow{2}{*}{$\begin{array}{l}\text { Sample } \\
\text { Source }\end{array}$} & \multirow{2}{*}{$\begin{array}{l}\text { No. of Analyzed } \\
\text { Samples }\end{array}$} & \multicolumn{3}{|c|}{ Adulterated Samples } & \multirow{2}{*}{$\begin{array}{l}\text { Detected } \\
\text { Pesticide }\end{array}$} & \multirow{2}{*}{$\begin{array}{c}\text { Residue } \\
\text { Level (ppm) }\end{array}$} & \multirow{2}{*}{$\begin{array}{l}\text { MRL } \\
(\mathrm{ppm})\end{array}$} \\
\hline & & Total & Single Pesticide & Multiple Pesticides & & & \\
\hline \multirow{2}{*}{ Producer } & \multirow{2}{*}{9} & \multirow{2}{*}{2} & 1 & \multirow{2}{*}{-} & Aldrin & 0.617 & \multirow{8}{*}{0.1} \\
\hline & & & 1 & & Aldrin & 0.812 & \\
\hline \multirow{6}{*}{ Retailer } & \multirow{6}{*}{9} & \multirow{6}{*}{4} & 1 & \multirow{2}{*}{-} & Aldrin & 0.332 & \\
\hline & & & 1 & & Aldrin & 0.479 & \\
\hline & & & \multirow{2}{*}{-} & \multirow{2}{*}{1} & Aldrin & 0.818 & \\
\hline & & & & & Dieldrin & 0.762 & \\
\hline & & & \multirow{2}{*}{-} & \multirow{2}{*}{1} & Aldrin & 0.967 & \\
\hline & & & & & Endrin & 0.828 & \\
\hline Control & 9 & - & - & - & Not detected & - & - \\
\hline
\end{tabular}

MRL, maximum residue limit, as recommended by the Australian Pesticides and Veterinary Medicines Authority [21] and the US Food and Drug Administration (FDA) [22].
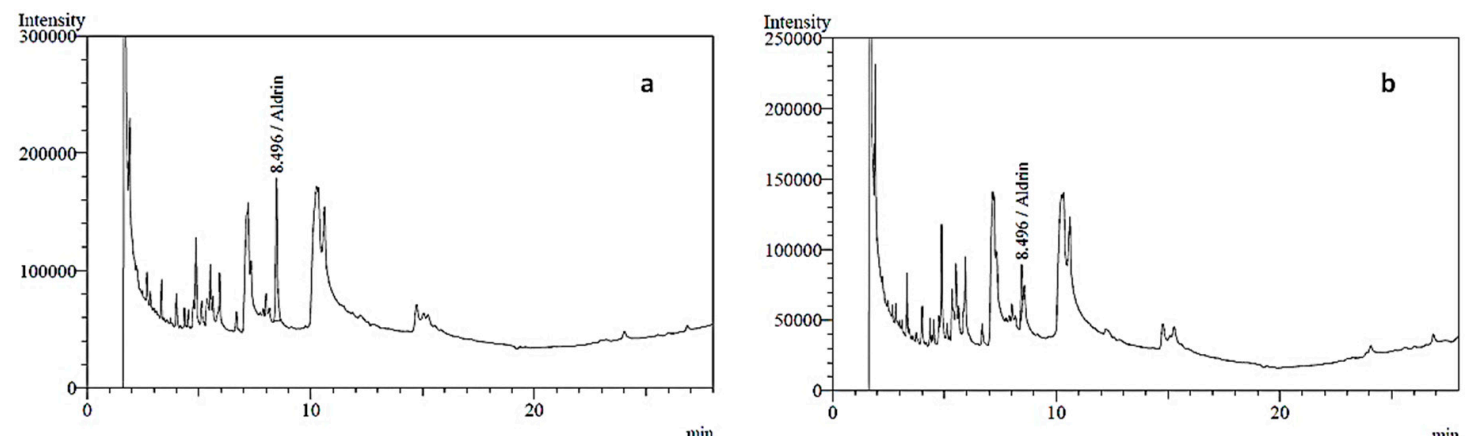

Figure 1. Chromatographs of detected pesticides in dried barb fish from producers (a) Aldrin (b) Aldrin.

\subsection{Microbiological Analysis}

\subsubsection{Total Plate Count}

Total plate count (TPC) of dried barb is presented in Table 2. Every month, TPC of retailer samples was found to be the highest $(p<0.05)$ among the analyzed samples, followed by producer and control. TPC of retailer samples measured between $6.2 \pm 0.02 \operatorname{log~cfu~g}^{-1}$ and $6.4 \pm 0.02 \log \mathrm{cfu} \mathrm{g}^{-1}$. The highest TPC of dried barb from producers was $5.4 \pm 0.03 \log _{\mathrm{cfu} \mathrm{g}}{ }^{-1}$, while the lowest was $5.3 \pm 0.02 \log \mathrm{cfu}$ $\mathrm{g}^{-1}$. TPC of control sample ranged between $5.0 \pm 0.03 \mathrm{log}_{\mathrm{cfu} \mathrm{g}}{ }^{-1}$ and $5.2 \pm 0.04 \log \mathrm{cfu} \mathrm{g}^{-1}$. 

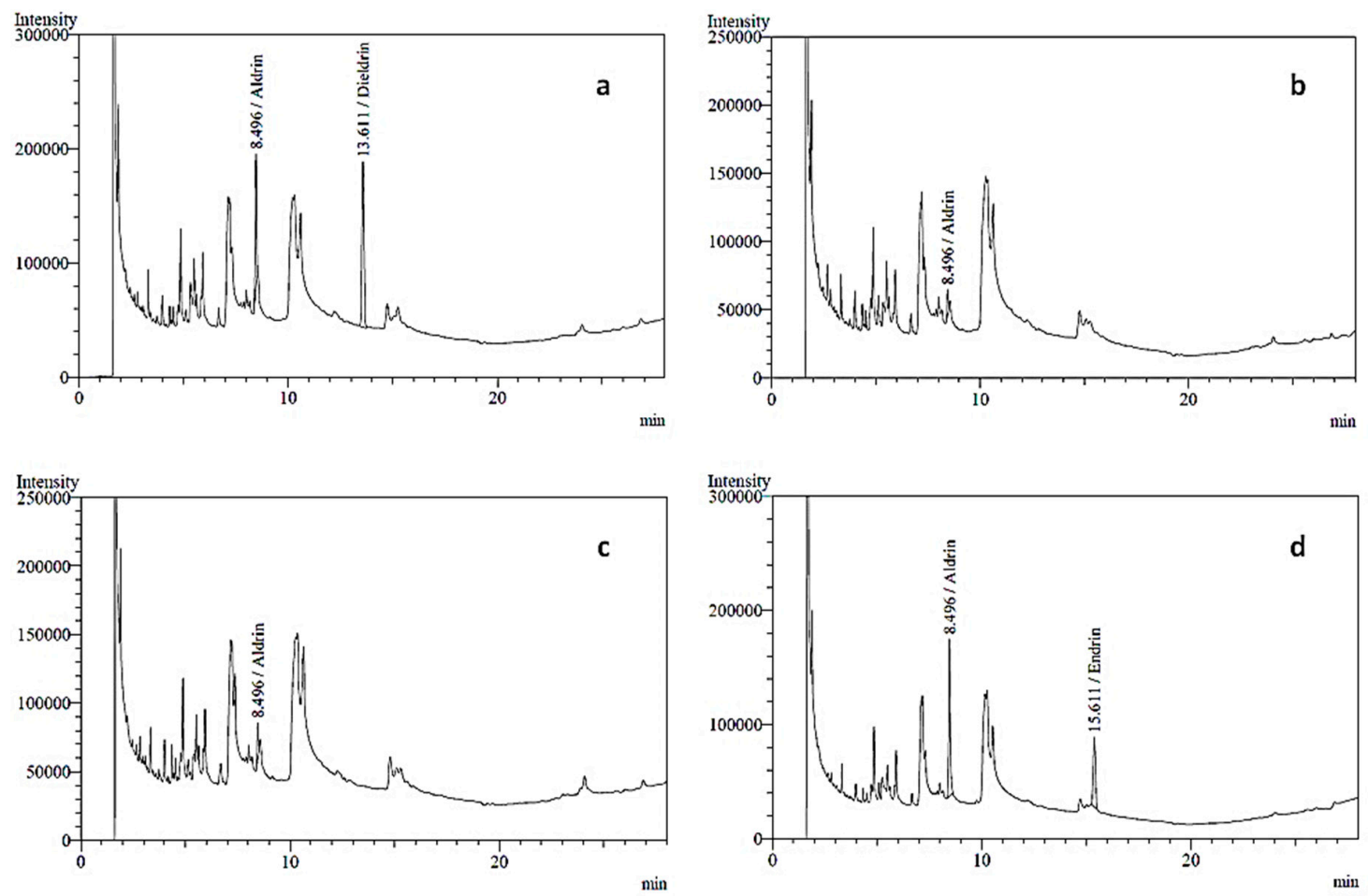

Figure 2. Chromatographs of detected pesticides in dried barb fish from retailers (a) Aldrin and dieldrin (b) Aldrin (c) Aldrin (d) Aldrin and endrin.

Table 2. Total plate count (TPC) of dried barb from the northeastern region of Bangladesh from December 2016 to April 2017.

\begin{tabular}{lccc}
\hline \multirow{2}{*}{ Month } & \multicolumn{3}{c}{ TPC $(\log$ value $)$ cfu g $^{-1}$} \\
\cline { 2 - 4 } & Control & Retailer & Producer \\
\hline December 2016 & $5.1 \pm 0.03^{\mathrm{c}}$ & $6.3 \pm 0.03^{\mathrm{a}}$ & $5.4 \pm 0.03^{\mathrm{b}}$ \\
January 2017 & $5.0 \pm 0.03^{\mathrm{c}}$ & $6.2 \pm 0.02^{\mathrm{a}}$ & $5.3 \pm 0.03^{\mathrm{b}}$ \\
February 2017 & $5.1 \pm 0.05^{\mathrm{c}}$ & $6.3 \pm 0.06^{\mathrm{a}}$ & $5.3 \pm 0.02^{\mathrm{b}}$ \\
March 2017 & $5.2 \pm 0.04^{\mathrm{c}}$ & $6.4 \pm 0.01^{\mathrm{a}}$ & $5.4 \pm 0.02^{\mathrm{b}}$ \\
April 2017 & $5.2 \pm 0.01^{\mathrm{c}}$ & $6.4 \pm 0.02^{\mathrm{a}}$ & $5.4 \pm 0.01^{\mathrm{b}}$ \\
\hline
\end{tabular}

Values are means \pm SEM, $n=3$ per treatment group. Letters in each row indicate significant differences $(p<0.05)$.

\subsubsection{Isolation and Identification of Bacteria}

E. coli was found in $100 \%, 100 \%$, and $33.3 \%$ of analyzed samples from producers, retailers, and control, respectively $\left(\chi^{2}=25.71, \mathrm{df}=2, p=0.000\right)$, whereas Salmonella sp. was observed in $13.3 \%$ (producer), $20 \%$ (retailer), and $0 \%$ (control) $\left(\chi^{2}=3.15, \mathrm{df}=2, p=0.100\right)$. In case of Vibrio sp., the maximum count was observed for retailer samples, while producer and control samples showed none $\left(\chi^{2}=4.186, \mathrm{df}=2, p=0.101\right)$ (Table 3$)$. Chi-square test suggested that only the presence of $E$. coli in dried barb depended on the source $(p<0.05)$.

Table 3. Results of qualitative bacterial test for analyzed samples.

\begin{tabular}{|c|c|c|c|c|c|c|c|c|c|}
\hline \multirow{2}{*}{ Bacteria } & \multicolumn{3}{|c|}{ No. of Samples Analyzed } & \multicolumn{3}{|c|}{ Positive Percentage (\%) } & \multirow{2}{*}{$\chi^{2}$ Value } & \multirow{2}{*}{ df } & \multirow{2}{*}{$p$ Value } \\
\hline & Producer & Retailer & Control & Producer & Retailer & Control & & & \\
\hline E. coli & 15 & 15 & 15 & 100 (15) & 100 (15) & $33.3(5)$ & 25.71 & 2 & 0.000 \\
\hline Salmonella sp. & 15 & 15 & 15 & $13.3(2)$ & $20(3)$ & $0(0)$ & 3.15 & 2 & 0.100 \\
\hline Vibrio sp. & 15 & 15 & 15 & $0(0)$ & $13.3(2)$ & $0(0)$ & 4.186 & 2 & 0.101 \\
\hline
\end{tabular}




\subsubsection{Fungal Counts}

Fungal counts of dried barb collected from producers, retailers, and control from December 2016 to April 2017 are given in Table 4. In every month, among the three samples, the highest fungal count was determined from retailers followed by retailers and control, although there were no significant differences observed between retailer and producer samples $(p<0.05)$. Fungal count was estimated from $3.4 \pm 0.04 \log \mathrm{cfu} \mathrm{g}^{-1}$ to $3.6 \pm 0.03 \mathrm{log}_{\mathrm{cfu} \mathrm{g}}{ }^{-1}$ for retailer samples, from $3.2 \pm 0.04$ to $3.5 \pm 0.04$ $\log$ cfu g $^{-1}$ for producers, and from $2.2 \pm 0.05$ to $2.5 \pm 0.03 \log$ cfu g $^{-1}$ for control.

Table 4. Fungal counts of dried barb from northeastern region of Bangladesh from December 2016 to April 2017.

\begin{tabular}{cccc}
\hline \multirow{2}{*}{ Month } & \multicolumn{3}{c}{ Fungal Count (log cfu g $^{\mathbf{- 1}}$ ) } \\
\cline { 2 - 4 } & Control & Retailer & Producer $^{\mathrm{a}}$ \\
\hline December 2016 & $2.4 \pm 0.04^{\mathrm{b}}$ & $3.5 \pm 0.04^{\mathrm{a}}$ & $3.4 \pm 0.04^{\mathrm{a}}$ \\
January 2017 & $2.2^{\mathrm{b}} \pm 0.05^{\mathrm{b}}$ & $3.4 \pm 0.04^{\mathrm{a}}$ & $3.2 \pm 0.04^{\mathrm{a}}$ \\
February 2017 & $2.3 \pm 0.05^{\mathrm{b}}$ & $3.5 \pm 0.02^{\mathrm{a}}$ & $3.3 \pm 0.02^{\mathrm{a}}$ \\
March 2017 & $2.4 \pm 0.05^{\mathrm{b}}$ & $3.6 \pm 0.02^{\mathrm{a}}$ & $3.5 \pm 0.02^{\mathrm{a}}$ \\
April 2017 & $2.5 \pm 0.03^{\mathrm{b}}$ & $3.6 \pm 0.03^{\mathrm{a}}$ & $3.5 \pm 0.04^{\mathrm{a}}$
\end{tabular}

Values are means $\pm \mathrm{SEM}, n=3$ per treatment group. Letters in each row indicate significant differences $(p<0.05)$.

\section{Discussion}

The present study found pesticides in dried barb. The presence of pesticides in dried fish was also reported in several other studies. Hasan et al. [8] estimated $0.204 \mathrm{ppm}$ and $0.034 \mathrm{ppm}$ of DDT in dried barb of Sayedpur and Cox's Bazar, respectively. They also reported that dichlorvos was not found in dried barb. Similarly, Chowdhury et al. [23] detected $0.187 \mathrm{ppm}$ and $0.243 \mathrm{ppm}$ of DDT in dried P. sophore collected from different markets of Dhaka city. DDT was also found in other dried fish such as Bombay duck and ribbon fish $[7,8,10,24]$. Aldrin was found in dry and wet fish collected from South Patches of the Bay of Bengal in amounts of 26 to $86 \mathrm{ng} \mathrm{g}^{-1}$ and 17 to $67 \mathrm{ng} \mathrm{g}^{-1}$, respectively [25-27]. These studies reported that dried fish producers or vendors indiscriminately used pesticides in dried fish. However, we did not study residues of aldrin and its derivatives in wet fish.

The presence of multiple pesticides (DDT-heptachlor) in dried ribbon fish, Bombay duck, anchovy, Chinese pomfret, and Indian salmon was also reported [10,24], which is similar to the findings of the present study. The detection of multiple pesticides in dried fish of retail markets revealed that anglers might use more than one pesticide in dried fish. Another explanation could be that one pesticide might be used by producers and another might be used by dried fish value chain vendors for long-term preservation of fish. At present, importing and producing the "Dirty Dozen" pesticides are prohibited in Bangladesh [28]. The persistent organochlorine pesticides (POPs) group known as the "Dirty Dozen" includes 12 substances: 9 agrochemicals (aldrin, chlordane, DDT, dieldrin, endrin, mirex, heptachlor, hexachlorobenzene, and toxaphene) and 3 industrial substances (polychlorinated biphenyls, dioxin, and furans) [29]. At present there is no legal use of any POPs in Bangladesh, but some old stocks may be available and some might be available through other unknown sources [28]. Besides, the use and production of aldrin, dieldrin, and endrin are prohibited or severely restricted by the Stockholm Convention on POPs [30]. The government of Bangladesh signed the Stockholm Convention on POPs, and has taken up the task of generating general awareness of consequences of POP release and ultimate elimination [28]. The persistence of endrin in the environment depends greatly on local circumstances. Some reports indicate that endrin can stay in soil for over 10 years [31].

Patterson and Ranjitha [32] reported higher TPC in commercially dried fish than laboratory-made dried fish, which parallels the results of the present study. Logesh et al. [33] found the highest TPC of $6.72 \log \mathrm{cfu} \mathrm{g}^{-1}\left(5.3 \times 10^{6} \mathrm{cfu} \mathrm{g}^{-1}\right)$ in dried Sardinella longiceps from Cuddalore, India. Likewise, Saritha et al. [18] observed maximum bacterial counts of $6.32 \mathrm{log} \mathrm{cfu} \mathrm{g}{ }^{-1}\left(2.13 \times 10^{6} \mathrm{cfu} \mathrm{g}^{-1}\right)$ in 
dried Paraupeneus indicus. A bacterial load of $5.36 \mathrm{log} \mathrm{cfu} \mathrm{g}^{-1}\left(2.3 \times 10^{5} \mathrm{cfu} \mathrm{g}^{-1}\right)$ in dried barb (Puntius sp.) collected from Natore, Bangladesh, was estimated by Islam et al. [34]. Monthly variations in temperature and moisture content in the atmosphere might be the reason for the variation of TPC in different months [33], which is also supported by Lilabati and Vishwanath [20] and Prakash et al. [19], who found that there was a direct connection between bacterial counts and moisture content of dried fish.

More E. coli in commercial dried fish than experimental dried fish was reported by Patterson and Ranjitha [32], which coincides with the findings of the current study. Saritha et al. [18], Prakash et al. [19], and Immaculate et al. [14] found E. coli in all the analyzed dried fish. The occurrence of $E$. coli indicates that dried fish might be polluted with total and fecal coliforms. The possible sources of coliform contamination in dried fish are fecal contamination in the landing center and washing fish in contaminated water [18].

Contamination of fish and fishery products with Salmonella and Vibrio sp. has been reported in different regions of India [14,19,33] and Bangladesh [35,36]. However, Azam et al. [3] and Saritha et al. [18] did not find Vibrio sp. and Salmonella sp. in dried fish. The occurrence of pathogenic microorganisms in dried fish might be attributed to external contamination [37]. In some cases, foodborne disease such as scombroid poisoning is observed in dried fish, mostly because of the chemical agent histamine, also known as histamine poisoning. Production of histamine in dried fish is caused by E. coli [33].

Kumar [38] estimated the highest fungal count of $4.27 \operatorname{log~cfu~g}^{-1}\left(1.5 \times 10^{4} \mathrm{cfu} \mathrm{g}^{-1}\right)$ in dried fish from the southeast coast of India. Similarly, Saritha et al. [18] found a maximum fungal count of $4.32 \mathrm{log} \mathrm{cfu} \mathrm{g}^{-1}\left(2.1 \times 10^{4} \mathrm{cfu} \mathrm{g}^{-1}\right)$ in dried fish of Cuddalore, India. The present study found a higher fungal count in commercially produced dried fish than the control sample, which parallels the findings of Patterson and Ranjitha [32]. Higher fungal count in dried fish might be associated with post-harvest delay, inappropriate transport, unhygienic treatment and processing during salting and sun-drying, unclean working floor, salt and water, and inadequate packaging [18]. Furthermore, the existence of different kinds of microorganisms in dried fish has been reported $[18,19,33,38]$. The fungus Aspergillus flavus is responsible for the production of aflatoxin, and has also been found to be responsible for foodborne intoxication, which results in serious health issues. Hasehm [39] reports that Aspergillus is the main genus commonly involved in the production of mycotoxins in fish. Therefore, the incidence of these fungi is of great significance in view of food safety and quality.

\section{Materials and Methods}

\subsection{Study Area and Sampling}

Dried barb fish (P. sopohre) were collected for a period of 5 months (December 2016 to April 2017, peak season for dry fish processing) from dried fish producers and retailers in the northeastern part of Bangladesh (Figure 3). Collected samples were packaged in sterile airtight polythene bags and immediately brought to the laboratory of Fish Processing and Quality Control, Sylhet Agricultural University (SAU), Bangladesh. In addition, 1 control sample was prepared to compare the results. To prepare the control sample, raw barb was collected from the same raw fish lot used by the producers and prepared in laboratory conditions after following the FAO Code of Practice for fish and fishery products [40]. Three consignment packets were monitored and tracked to trace the products from 3 different retailers. Sampling for each month, samples from retailers were collected after 7 days of receiving dried fish products. Pesticide analysis was carried out in the Pesticide Analytical Laboratory of Bangladesh Agricultural Research Institute (BARI), Bangladesh. Microbiological analysis was conducted in the laboratory of Microbiology and Immunology, SAU. 


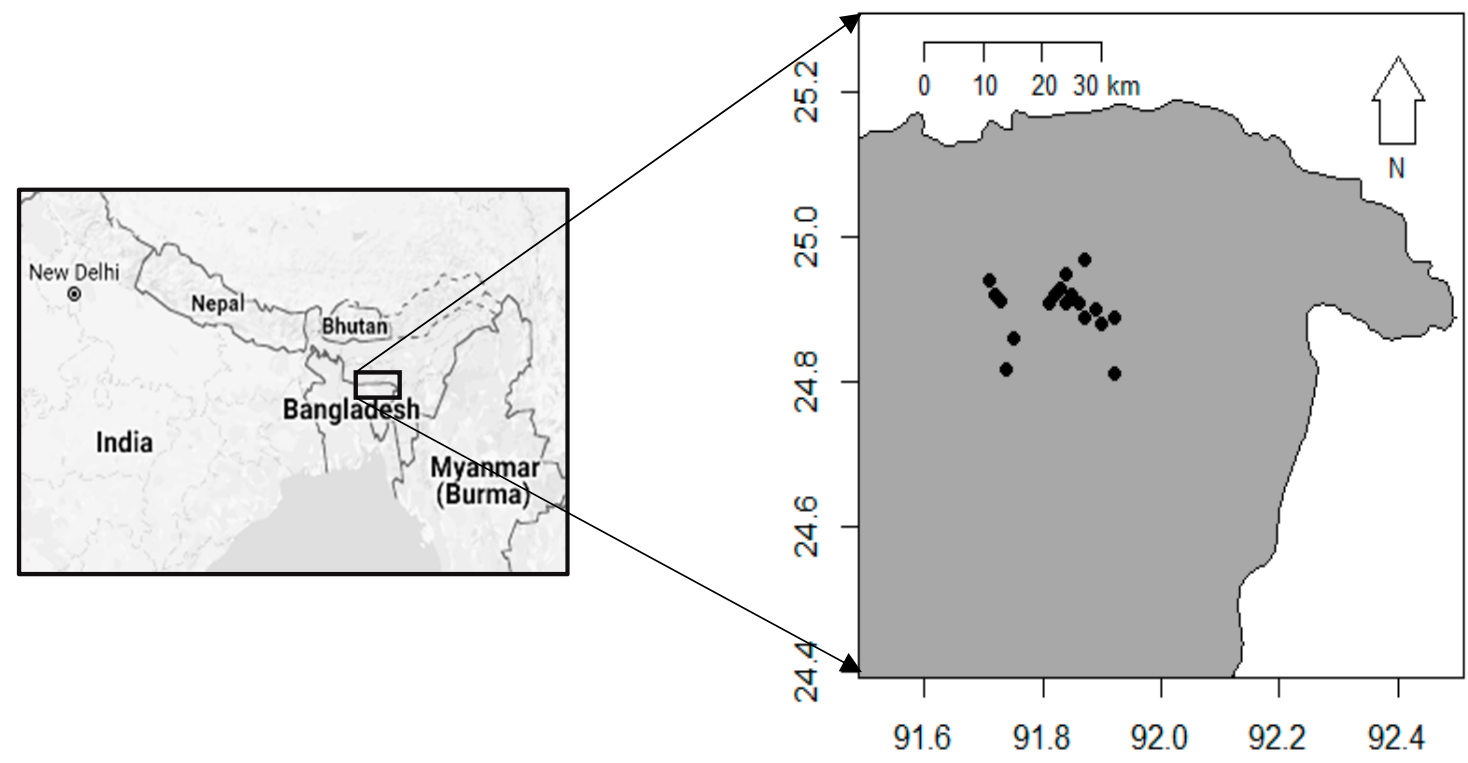

Figure 3. Map of the study area.

\subsection{Organochlorine Pesticide Residue Analysis}

\subsubsection{Sample Preparation, Extraction, and Cleanup}

The extractions were carried out according to the quick, easy, cheap, effective, rugged, and safe (QuEChERS) method described by Anastassiades et al. [41], with some necessary modifications. Samples were chopped on a chopping board with a sharp knife and ground, then $10 \mathrm{~g}$ of chopped sample was transferred to a $50 \mathrm{~mL}$ Teflon centrifuge tube. Then $10 \mathrm{~mL}$ of acetonitrile was added to the centrifuge tube and agitated well for proper mixing, followed by addition of $7.5 \mathrm{~g}$ of anhydrous $\mathrm{MgSO}_{4}$ and $1 \mathrm{~g}$ of $\mathrm{NaCl}$, and the centrifuge tube was vigorously shaken for $1 \mathrm{~min}$. Later it was centrifuged at $5000 \mathrm{rpm}$ for $5 \mathrm{~min}$. After centrifugation, $2 \mathrm{~mL}$ of the supernatant was transferred to an Eppendorf tube containing $100 \mathrm{mg}$ of primary secondary amine (PSA), $150 \mathrm{mg}$ of $\mathrm{MgSO}_{4}$, and $100 \mathrm{mg}$ of charcoal for cleanup, followed by vigorous shaking for $2 \mathrm{~min}$. Again, the prepared sample extract was centrifuged at 10,000 rpm for $5 \mathrm{~min}$. Afterward, the sample extract was filtered through a $0.45 \mu \mathrm{m}$ filter using a syringe and transferred to a vial for further GC analysis.

\subsubsection{GC Analysis}

The organochlorine pesticide residues were analyzed by a Shimadzu GC-2010 with an electron capture detector (ECD), an auto-injector (AOC 20i; Shimadzu, Kyoto, Kyoto Prefecture, Japan), and GC solution software. The capillary column used in ECD was Rtx-CL, $30.0 \mathrm{~m}$ length $\times 0.25 \mathrm{~mm}$ ID $\times 0.32 \mu \mathrm{m}$ film thickness. The GC was run under the following conditions: injector temperature: $250{ }^{\circ} \mathrm{C}$; detector temperature $330^{\circ} \mathrm{C}$; oven temperature: $260^{\circ} \mathrm{C}$ starting from 0 to $180^{\circ} \mathrm{C}$ for $0 \mathrm{~min}$ and continued at $5{ }^{\circ} \mathrm{C} \mathrm{min}-1$ to $220^{\circ} \mathrm{C}$, held for $12 \mathrm{~min}$, and continued at $5^{\circ} \mathrm{C} \mathrm{min}-1$ to $260{ }^{\circ} \mathrm{C}$; injected sample volume: $1 \mu \mathrm{L}$; mode of injection: split; carrier gas: $\mathrm{N}_{2}$ with a $77.8 \mathrm{kPa}$ flow rate; runtime: $28 \mathrm{~min}$. Standard peaks were detected by inserting a high concentration of the standard (1 ppm), and the retention time for organochlorine pesticides was estimated (Figure 4). Composite stock standard solution was used to conduct the calibration at 5 points $(25,50,100,200$, and $300 \mathrm{ppb})$. The GC system was calibrated using an external standard technique. Individual standard stock solution (100 $\mathrm{mg} \mathrm{L}^{-1}$ ) was prepared by weighing appropriate amounts of active ingredients in a brown bottle with a Teflon-lined screw cap and dissolving the weighed standard in HPLC-grade methanol. To prepare primary dilution standards, stock standard solution was used. An appropriate volume of each individual stock solution was transferred to a volumetric flask and the solutions were mixed to acquire stock standard solution [41]. 


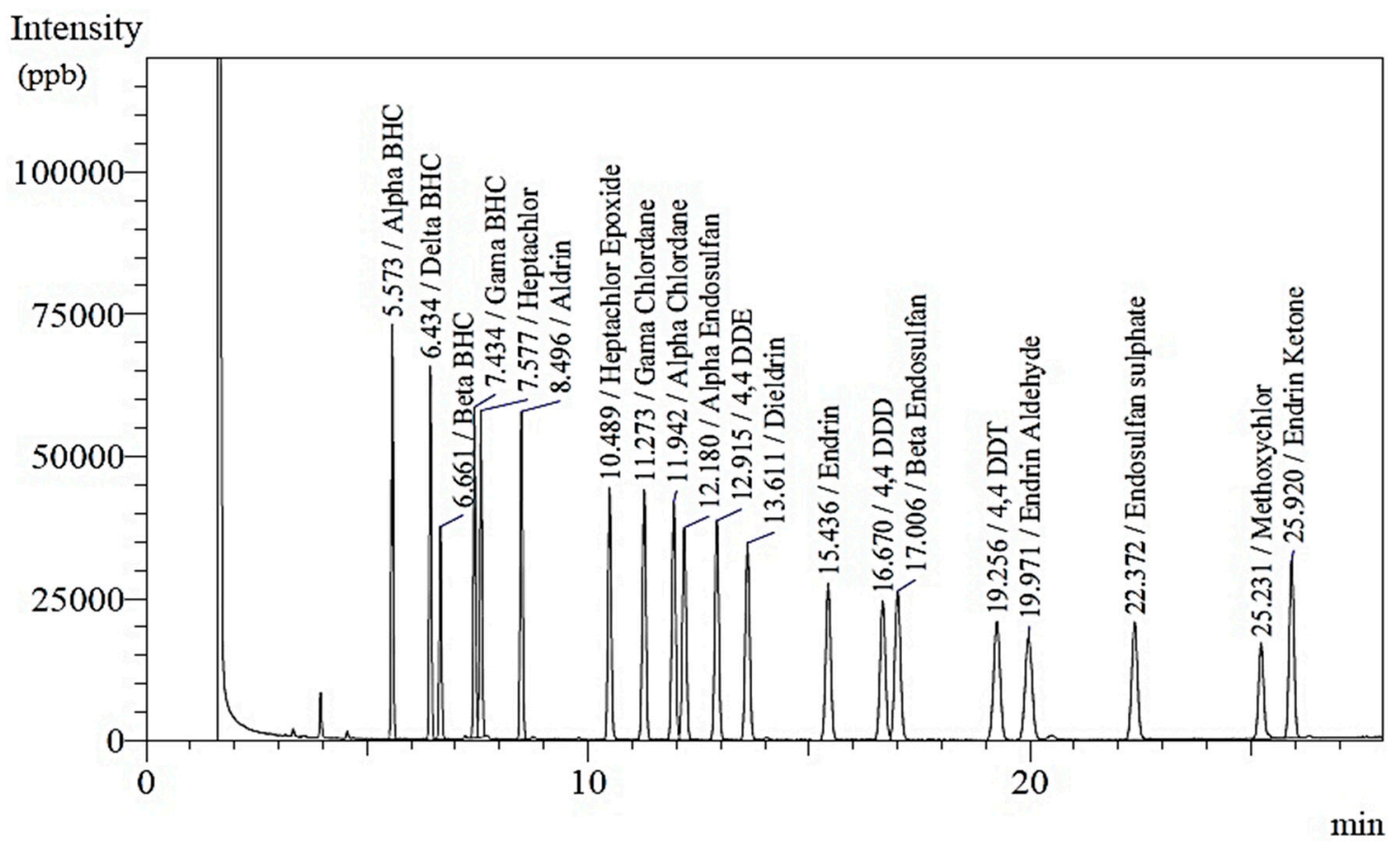

Figure 4. Chromatograms of 20 standard organochlorine pesticide run by gas chromatography with electron capture detector (GC-ECD).

\subsubsection{Analytical Quality Control}

A gas chromatograph equipped with ECD was tested for linearity. One microgram per liter was the instrumental limit of detection of GC-ECD for organochlorine pesticides. An aliquot of dried fish sample, which was collected as blank and treated precisely as a sample including exposure to all glassware, equipment, solvents, and reagents, was used with the sample matrix. In the laboratory reagent blank, no analytic peak was detected. An aliquot of fortified sample matrix was made, to which known amounts of the pesticides were mixed in the laboratory in ppb range. This laboratory-fortified matrix was examined exactly like the sample. Extraction and cleanup were carried out as mentioned and the recovery from untreated control samples of dry fish fortified with the analyzed compounds at a level of $25 \mathrm{ppb}$ was $96-100 \%$ for organochlorine mix. Before injection of the first sample solution, a standard solution was injected at least 3 times to check the opening conditions, and the constancy of the detector signal was checked by injecting serial dilutions of organochlorine mix [41].

\subsubsection{Quantification of Detected Pesticide}

Any pesticide detected from the tested samples was identified and quantified by the chromatogram of standard pesticides. Sample results were quantified in ppm automatically by the GC software, which represented the concentration of the final volume injected [41]. From this value, the actual amount of organochlorine pesticide residue present in the sample was estimated through the following formula:

Amount of pesticide residue $=$ (conc. of obtained pesticide in injected sample $(\mathrm{ppm}) \times$ quantity of final volume $(\mathrm{L})) /($ amount of sample taken $(\mathrm{kg}))$

\subsection{Microbiological Quality Analysis}

\subsubsection{Total Plate Count (TPC)}

A spread plate method [42] was used to estimate total aerobic bacterial counts of dried barb fish. Twenty-five (25) g of sample was suspended in $225 \mathrm{~mL}$ of Butterfield's buffered phosphate diluent. 
One milliliter of aliquot of homogenate solution was serially diluted $\left(10^{-2}\right.$ to $\left.10^{-6}\right)$. Then $0.1 \mathrm{~mL}$ of aliquot was inoculated on triplicate plate count agar (Difco, Gurgaon, Haryana, India) and incubated at $35{ }^{\circ} \mathrm{C}$ for $48 \mathrm{~h}$. Plates containing 30-300 colonies were used to calculate bacterial population results, recorded as colony forming units of sample. For each sample, TPC $\left(\mathrm{cfu} \mathrm{g}^{-1}\right)$ was done in triplicate.

\subsubsection{Fungal Count}

Samples were prepared in the same way as the aerobic plate count method. Samples were inoculated on Sabourad dextrose agar (Himedia, Mumbai, Maharashtra, India) and incubated at $23^{\circ} \mathrm{C}$ in inverted position for 5 days. Colonies of fungus were counted as colony forming units from the plates with 10-100 colonies. TPC ( $\left.\mathrm{cfu} \mathrm{g}^{-1}\right)$ was done in triplicate [43].

\subsubsection{Isolation and Identification of Bacteria}

To isolate different bacteria in dried barb fish, bacterial colonies were divided into groups according to colony shape, size, elevation, structure, surface, edge, color, and opacity and the number of colonies of each recognizable type were counted. With some exceptions, 3 to 5 representatives of each colony type were then streaked repeatedly on tryptic soya agar (TSA) plates until pure cultures were obtained. For all populations, an average of $5 \%$ of primary isolates failed to grow despite repeated attempts at subsequent subculture. Purified cultures were inoculated onto TSA slants and kept at $48{ }^{\circ} \mathrm{C}$ to get stock inoculums, then the inoculums were again cultured on agar slants every 6 weeks [43]. Bacteria were identified according to the criteria described in Bergey's Manual of Determinative Bacteriology [44] up to genus and species level. A total of 15 samples from each source were analyzed to isolate and identify bacteria.

\subsection{Data Analysis}

All data were subjected to statistical analysis. One-way ANOVA and post hoc Tukey's test were used to analyze values of TPC and fungal count [45] and the differences within variables [46]. ANOVA was performed on log-transformed values to assure data normality. Values are expressed as mean \pm SEM; $p$ values $<0.05$ were considered statistically significant. Meanwhile, data from qualitative microbiological tests were analyzed using the chi-square test with SPSS statistical software (version 23, IBM, Armonkcity, New York, USA). A map was generated using R (version 3.2.4).

\section{Conclusions}

The present study revealed that anglers have been using organochlorine pesticides in dried barb fish without considering their health hazards. Concentrations of the detected pesticides were much higher than recommended MRLs, which might cause health problems for consumers for a long time. Besides, the microbiological quality of died barb fish was found to be very poor. The government of Bangladesh should take all necessary initiatives to tackle this situation. It can be done by implementing existing legislation, increasing awareness about the harmful effect of these pesticides, and barring the trade of harmful pesticides on the market. In addition, anglers should dry fish properly and package it very carefully so that the dried fish cannot absorb moisture from the environment. The small sample size and localized sampling location limit the findings compared to the whole of Bangladesh. Further studies are required to reveal the residual limits of other pesticides with more geographical coverage and larger sample sizes.

Author Contributions: Conceptualization, M.A.H. and M.A.S.; methodology, M.A.H., A.T.M.M.E.-E.-E., and M.A.S.; Formal analysis, M.A.H., M.L.K., M.J.I., and M.S.A.; Funding acquisition, M.A.S. and M.J.I.; Supervision, M.A.S., A.T.M.M.E.-E.-E., and M.S.A.; Resources, A.T.M.M.E.-E.-E. and M.S.A.; Visualization, M.A.H. and M.J.I.; writing—original draft preparation, M.A.H. and M.S.A.; writing—review and editing, M.J.I., M.A.H., and A.T.M.M.E.-E.-E.

Funding: This research was funded by the Ministry of Science and Technology, Government of Bangladesh, grant number CRG 489. 
Acknowledgments: The authors would like to thank the Pesticide Analytical Laboratory, BARI, Gazipur Bangladesh, and the Laboratory of Microbiology and Immunology, SAU, Sylhet, Bangladesh, for helping with the laboratory analysis.

Conflicts of Interest: The authors declare no conflict of interest.

\section{References}

1. DoF. Yearbook of Fisheries Statistics of Bangladesh 2016-17; Fisheries Resources Survey System (FRSS), Department of Fisheries: Dhaka, Bangladesh, 2017.

2. Khan, M.A.A.; Khan, Y.S.A. Insect Infestation and Preventive Measures in Dry Fish Storage of Chittagong, Bangladesh. Int. J. Biol. Sci. 2001, 1, 963-965.

3. Azam, K.; Bashar, M.M.; Ali, M.Y.; Asaduzzaman, M.; Hossain, M.M. Comparative Study of Organoleptic, Microbiological and Biochemical Qualities of Four Selected Dried Fish in Summer and Winter. Pakistan J. Biol. Sci. 2003, 6, 2030-2033.

4. Wall, R.; Howard, J.J.; Bindu, J. The Seasonal Abundance of Blowflies Infesting Drying Fish in South-West India. J. Appl. Ecol. 2001, 38, 339-348. [CrossRef]

5. Flowra, F.A.; Tumpa, A.S.; Islam, M.T. Study on the Insect Infestation of Dry Fishes at Singra. J. Asiat. Soc. Bangladesh Sci. 2014, 39, 273-277. [CrossRef]

6. Walker, D.J.; Wood, C.D. Non-Insecticidal Methods of Reducing Losses Caused by Infestation of Blow-Flies (Diptera) during Fish Curing Procedures; FAO: Rome, Italy, 1986.

7. Siddique, M.A.M.; Aktar, M. Detection of Health Hazard Insecticide Dichlorodiphenyltrichloroethane (DDT) in Some Common Marine Dry Fish Samples from Bangladesh. Health 2012, 4, 185-189. [CrossRef]

8. Hasan, M.N.; Islam, H.M.R.; Ahmed, K.K.U.; Mahmud, Y.; Siddiqee, S. Screening and Quantification of Dichlorodiphenyltrichloroethane (DDT) and Dichlorovos in Selected Dry Fish Species of Bangladesh by GC-ECD Detector. Int. J. Sci. Res. Manag. 2013, 1, 352-353.

9. Hasan, M.N.; Islam, H.M.R.; Akter, R.; Mahmud, Y.; Ahmed, K.K.U.; Siddiquee, S. Determination of Dichlorodiphenyltrichloroethane Residues Levels in Commercial Marine Dry Fish from Different Regions of Bangladesh. Annu. Res. Rev. Biol. 2014, 4, 2722-2729. [CrossRef]

10. Bhuiyan, N.H.; Bhuiyan, H.; Ahmed, K.; Dawlatana, M.; Haque, K.M.F.; Rahim, M.; Bhuiyan, N.I. Organochlorine Insecticides (DDT and Heptachlor) in Dry Fish: Traditional Washing and Cooking Effect on Dietary Intake. Bangladesh J. Pharmacol. 2009, 4, 46-50. [CrossRef]

11. Graikoski, J.T. Microbiology of Cured and Fermented Fish. In Microbial Safety of Fisheries Products; Chichester, C.O., Graham, H.D., Eds.; Academic Press: New York, NY, USA, 1973; pp. 249-255.

12. Islam, M.J.; Sayeed, M.A.; Akhtar, S.; Hossain, M.S.; Liza, A.A. Consumers Profile Analysis Towards Chicken, Beef, Mutton, Fish and Egg Consumption in Bangladesh. Br. Food. J. 2018, 120, 2818-2831. [CrossRef]

13. Proctor, D.L. The Protection of Smoke-Dried Freshwater Fish from Insect Damage during Storage in Zambia. J. Stored Prod. Res. 1972, 8, 139-149. [CrossRef]

14. Immaculate, K.; Sinduja, P.; Velammal, A.; Patterson, J. Quality and Shelf Life Status of Salted and Sun Dried Fishes of Tuticorin Fishing Villages in Different Seasons. Int. Food Res. J. 2013, 20, 1855-1859.

15. Pawsey, R.; Davies, R. Safety of Intermediate Moisture Foods with Respect to Staphylococcus aureus. Intermed. Moisture Foods 1976, 68, 1864-1871.

16. FAO (Food \& Agriculture Organization). Perspective on Mycotoxins: Selected Documents of the Joint FAO/WHO/UNEP Conference on Mycotoxins Held in Nairobi, 19-27 September 1977. In Perspective on Mycotoxins: Selected Documents of the Joint FAO/WHO/UNEP Conference on Mycotoxins held in Nairobi; FAO: Rome, Italy, 1979.

17. Mugula, J.K.; Lyimo, M.H. Microbiological Quality of Traditional Market Cured Fish in Tanzania. J. Food Saf. 1992, 13, 33-41. [CrossRef]

18. Saritha, K.; Immaculate, K.; Aiyamperumal, V.; Patterson, J. Microbial and Biochemical Qualities of Salted and Sun Dried Sea Foods of Cuddalore, Southeast Coast of India. Int. J. Microbiol. Res. 2012, 3, 138-143.

19. Prakash, S.; Jeyasanta, I.; Patterson, J. Microbial Quality of Salted and Sun Dried Sea Foods of Tuticorin Dry Fish Market, Southeast Coast of India. Int. J. Microbiol. Res. 2011, 2, 188-195.

20. Lilabati, H.; Vishwanath, W. Changes in Bacterial and Fungal Quality During Storage of Smoked, Esomus danricus of Manipur. Fish. Technol. 1999, 36, 36-39. 
21. Australian Pesticides and Veterinary Medicines Authority. Agricultural and Veterinary Chemicals Code Instrument No. 4 (MRL Standard) 2012; Australian Pesticides and Veterinary Medicines Authority: Symonston, Australia, 2014; pp. 1-264.

22. FDA. Compliance Policy Guides-CPG Sec. 575.100 Pesticide Residues in Food and Feed_Enforcement Criteria; FDA: Silver Spring, MD, USA, 2008.

23. Chowdhury, M.A.Z.; Amin-ud-Din, M.; Malek, M.A.; Zaman, M.A. DDT Residue and Its Metabolites in Dried Fishes of Dhaka City Markets. Soil Environ. 2010, 29, 117-121.

24. Bhuiyan, N.H.; Bhuiyan, H.R.; Rahim, M. Screening of Organochlorine Insecticides (DDT and Heptachlor) in Dry Fish Available in Bangladesh. Bangladesh J. Pharmacol. 2008, 3, 114-120. [CrossRef]

25. Jabber, S.M.A.; Khan, Y.S.A.; Rahman, M.S. Levels of Organochlorine Pesticide Residues in Some Organs of the Ganges Perch, Lates calcarifer, from the Ganges-Brahmaputra-Meghna Estuary, Bangladesh. Mar. Pollut. Bull. 2001, 42, 1291-1296. [CrossRef]

26. Das, B.; Khan, Y.S.A.; Das, P.; Shaheen, S. Organochlorine Pesticide Residues in Catfish, Tachysurus thalassinus (Ruppell, 1835), from the South Patches of the Bay of Bengal. Environ. Pollut. 2002, 120, 255-259. [CrossRef]

27. Das, B.; Das, P. Organochlorine Pesticide Residues in Water, Sediment, and Muscle of River Shad, Hilsa ilisha (Hamilton 1822) from the South Patches of the Bay of Bengal. Bull. Environ. Contam. Toxicol. 2004, 72, 496-503. [CrossRef] [PubMed]

28. ESDO. Country Situation Report on Persistent Organic Pollutants in Bangladesh Environment and Social Development Organization. In International POPs Elimination Project; Environment and Social Development Organization-ESDO: Dhaka, Bangladesh, 2005; pp. 1-33.

29. EPA. Persistent Organic Pollutants: A Global Issue, A Global Response. 2015. Available online: https: / / www. epa.gov/international-cooperation/persistent-organic-pollutants-global-issue-global-response (accessed on 8 June 2017).

30. World Health Organization. The Who Recommended Classification of Pesticides By Hazard and Guidelines to Classification 2009; World Health Organization: Geneva, Switzerland, 2010; pp. 1-60.

31. Taylor, J.; Spoo, J.W.; Kedderis, L.B. Toxicological Profile for Endrin; Agency for Toxic Substances and Disease Registry: Atlanta, GE, USA, 1996.

32. Patterson, J.; Ranjitha, G. Qualities of Commercially and Experimentally Sun Dried Fin Fish, Scomberoides tol. Afr. J. Food Sci. 2009, 3, 299-302.

33. Logesh, A.R.; Pravinkuma, M.; Raffi, S.M.; Kalaiselva, M. An Investigation on Microbial Screening on Salt Dried Marine Fishes. J. Food Resour. Sci. 2012, 1, 15-21. [CrossRef]

34. Islam, M.T.; Ahmed, S.; Sultana, M.A.; Tumpa, A.S.; Flowra, F.A. Nutritional and Food Quality Assessment of Dried Fishes in Singra Upazila under Natore District of Bangladesh. Trends Fish. Res. 2013, 2, 2319-4758.

35. Mrityunjoy, A.; Kaniz, F.; Fahmida, J.; Shanzida, J.S.; Aftab, U.; Rashed, N. Prevalence of Vibrio cholerae in Different Food Samples in the City of Dhaka, Bangladesh. Int. Food Res. J. 2013, 20, 1017-1022.

36. Sultana, N.; Siddique, M.P.; Farhana, Z.; Dina, M.A.; Uddin, M.I. Isolation and Identification of Bacteria From Dried Fishes Collected. Int. J. Biores. 2010, 2, 1-5.

37. Gopalakrishna Iyer, T.S.; Shrivastava, K.P. Incidence and Low Temperature Survival of Salmonella in Fishery Products. Fish. Technol. 1989, 26, 39-42.

38. Kumar, P.A. Bacterial Resistance to Antimicrobial Agents and Microbiological Quality among Escherichia coli Isolated from Dry Fishes in Southeast Coast of India. Sci. York 2008, 13, 3984-3989.

39. Hashem, M. Isolation of Mycotoxin-Producing Fungi from Fishes Growing in Aquacultures. Res. J. Microbiol. 2011, 6, 862-872. [CrossRef]

40. World Health Organization. Code of Practice for Fish and Fishery Products; Food and Agriculture Organization of the United Nations (FAO): New York, NY, USA, 2012.

41. Anastassiades, M.; Lehotay, S.J.; Štajnbaher, D.; Schenck, F.J. Fast and Easy Multiresidue Method Employing Acetonitrile Extraction/Partitioning and "Dispersive Solid-Phase Extraction" for the Determination of Pesticide Residues in Produce. J. AOAC Int. 2003, 86, 412-431. [PubMed]

42. Miwa, K.; Low, S.J. Aerobic Plate Count. In Laboratory Manual on Analytical Methods and Procedures for Fish and Fish Products; Marine Fisheries Research Development Southeast Asian Fisheries Development Center/JICA: Singapore, 1992.

43. Al-Harbi, A.H.; Uddin, N. Bacterial Diversity of Tilapia (Oreochromis niloticus) Cultured in Brackish Water in Saudi Arabia. Aquaculture 2005, 250, 566-572. [CrossRef] 
44. Holt, J.G.; Krieg, N.R.; Sneath, P.H.A.; Staley, J.T. Bergey's Manual of Determinative Bacteriology, 9th ed.; Williams and Wilkins: Baltimore, MD, USA, 1994.

45. Assaad, H.I.; Zhou, L.; Carroll, R.J.; Wu, G. Rapid Publication-Ready MS-Word Tables for One-Way ANOVA. Springerplus 2014, 3, 1-8. [CrossRef] [PubMed]

46. Bhujel, R.C. Statistics for Aquaculture; John Wiley \& Sons: Ames, IA, USA, 2009. 